\title{
Perbandingan Respon Caspase-3 Sel Trakea terhadap Radiasi Sinar Gamma Dosis Tunggal dan Dosis Fraksinasi
}

\author{
Berlian Cyntia Devi*, Yuyun Yueniwati**® ${ }^{*}$ Ahmad DW ***
}

\begin{abstract}
ABSTRAK
Radiasi sinar gamma adalah suatu modalitas terapi kanker, namun salah satu efek yang tidak diinginkan adalah kerusakan sel normal di sekeliling sel target. Salah satu organ yang sering terkena dampak adalah trakea. Penelitian ini bertujuan untuk membandingkan pemberian radiasi sinar gamma dosis tunggal 10 Gy (1x10 Gy) dapat menyebabkan ekspresi caspase-3 yang lebih tinggi daripada pemberian radiasi sinar gamma dosis fraksinasi $10 \mathrm{~Gy}$ (5x2 Gy) pada sel trakea. Studi eksperimental menggunakan one way ANOVA dilakukan terhadap hewan coba Rattus norvegicus galur Wistar, berusia 3-4 bulan dan berat badan seragam sekitar $200 \mathrm{~g}$. Sampel dibagi menjadi tiga kelompok dengan $n=9$, yaitu kelompok kontrol, kelompok radiasi dosis tunggal, dan kelompok radiasi dosis fraksinasi. Variabel tergantung dalam penelitian ini adalah respon caspase-3 sel trakea akibat radiasi sinar gamma. Hasil penelitian menunjukkan ekspresi caspase-3 pada radiasi dosis tunggal meningkat secara signifikan $(p<0,05)$. Namun pada pemberian radiasi dosis fraksinasi pada sel trakea tidak menunjukkan ekspresi caspase-3 yang bermakna $(p>0,05)$. Kesimpulan dari penelitian ini adalah pemberian radiasi sinar gamma dosis tunggal $10 \mathrm{~Gy}$ (1x10 Gy) dapat ,menyebabkan ekspresi caspase-3 yang lebih tinggi daripada pemberian radiasi sinar gamma dosis fraksinasi 10 Gy (5x2 Gy) pada sel trakea.
\end{abstract}

Kata kunci: Caspase-3, Radiasi, Sinar gamma, Trakea.

\section{Comparison of Caspase-3 Responses of Tracheal Cells to Gamma Rays Radiation in Single Dose and Fractination Dose}

\begin{abstract}
Gamma rays radiation is one of cancer therapy modalities but have unwanted effect that is da maging normal cells around target cells. One of many affected organs is trachea. This research wa $s$ to compare caspase-3 expression of tracheal cells against gamma rays radiation in single dose 1 $0 \mathrm{~Gy}(1 \times 10 \mathrm{~Gy})$ and fractination dose $10 \mathrm{~Gy}$ (5x2 Gy). This was an experimental study using one way ANOVA. The subject were Rattus norvegicus Wistar strain, with aged of 3-4 months and weight $200 \mathrm{~g}$. Sample divided into 3 groups $(n=9)$, those are control group, single dose radiation group, and fract ination dose group. Dependent variable in this research was caspase-3 expression in tracheal cell caused by gamma rays radiation. The result showed that caspase- 3 responses in single dose gam ma rays radiation was significantly increased $(p<0,05)$, but not significantly increased in fractinatio $n$ dose gamma rays radiation $(p>0,05)$. The conclusion of this research was single dose of gamma rays caused increased caspase- 3 responses higher than fractination dose of gamma rays radiation.

Keyword: Caspase-3, Gamma rays, Radiation, Trachea.

* Program Studi Pendidikan Dokter, FKUB

** Lab Radiologi, RSSA-FKUB

${ }^{* * *}$ Lab Telinga Hidung Tenggorokan- Kepala Leher, RSSA-FKUB
\end{abstract}

$\square$ Lab. Radiologi, RSSA-Fakultas Kedokteran Universitas Brawijaya, Jalan Veteran Malang, 65145

E-mail: yyueniwati@yahoo.com 


\section{PENDAHULUAN}

Radioterapi telah banyak digunakan untuk terapi pengobatan kanker dan terbukti memiliki efektivitas cukup tinggi. Radioterapi diberikan secara tunggal maupun dikombinasikan bersama dengan kemoterapi dan pembedahan. Prinsip kerja radioterapi menggunakan radiasi tingkat tinggi untuk menghancurkan sel kanker. Tujuan radioterapi adalah sebagai pengobatan secara radikal, terapi paliatif dan terapi adjuvant. Dalam prakteknya dikenal ada 2 macam radioterapi berdasarkan cara penyinaran yaitu interna dan eksterna. Penyinaran interna hanya untuk beberapa jenis kanker tertentu dan cakupannya relatif sempit. Penyinaran eksterna dapat diaplikasikan hampir semua jenis kanker. ${ }^{1}$

Dikenal dua macam pemberian radiasi ionisasi untuk terapi kanker yaitu dosis tunggal dan dosis fraksinasi. Pada terapi radiasi kanker dosis fraksinasi, beragam dosis dapat digunakan. Dosis awal berupa 3 sesi penyinaran dengan dosis total 18 Gy dan dapat dinaikkan hingga dosis standar yakni 30 sesi penyinaran selama 6 minggu dengan dosis 1,8 - 2 Gy per sesi dengan dosis total 50 - 60 Gy. ${ }^{2}$

Pada prinsipnya radioterapi memanfaatkan radiasi pengion sinar gamma yang berasal dari disintegrasi inti cobalt-60 radioaktif. Jika radiasi pengion mengenai sel kanker, akan menimbulkan ionisasi air sehingga membentuk radikal bebas yang bereaksi dengan DNA dan menyebabkan kerusakan DNA. ${ }^{3}$ Kematian sel tidak hanya terjadi pada sel kanker saja namun dapat juga menyebabkan kematian sel normal di sekitarnya. Kematian sel normal ini akibat efek samping dalam radioterapi. ${ }^{3}$

Apoptosis adalah suatu kematian sel terprogram. Apoptosis terjadi ketika sel sudah tidak lagi dibutuhkan oleh tubuh. Proses apoptosis melibatkan kaskade proteolitik khusus seperti caspase 3 yang menyebabkan sel mengerut, memadat, merusak sitoskeletonnya, dan mengubah permukaan selnya sehingga sel fagositik yang berdekatan, seperti makrofag, dapat menempel pada membran sel dan mencerna sel tersebut. ${ }^{4}$

Efek radiasi dapat dilihat pada berbagai macam organ, salah satunya pada trakea. Trakea bersifat radiosensitif dengan radiasi rendah, terutama pada bagian submukosa. Berdasarkan penelitian terdahulu diketahui bahwa penyinaran dengan dosis rendah (2 dan 2,5 Gy) pada trakea kelinci terjadi peningkatan aktivitas silia dan peningkatan jumlah sel goblet. Pada penyinaran dosis tunggal yang lebih tinggi (15 Gy) pada trakea menyebabkan pembengkakan ujung silia, kerusakan silia dan terjadi perlekatan antar silia. $^{5}$

Di sisi lain, kanker nasofaring adalah ka nker yang paling sering terjadi dengan angka kejadian mencapai $60 \%$ dari seluruh kasus $\mathrm{k}$ anker bagian kepala leher. Insiden kanker na sofaring menduduki peringkat keempat tertin ggi setelah kanker cervix, kanker payudara dan kanker kulit. Terapi yang paling efektif $u$ ntuk kanker ini adalah radioterapi. Pada pen gerjaannya sering sekali bagian trakea terke na

radiasi, karena trakea tidak dapat dilindungi secara sempurna. ${ }^{6}$ Trakea memiliki sifat radi osensitif sehingga mudah sekali mengalami kerusakan sampai keganasan jika terkena ra diasi. Hal inilah yang membuat peneliti ingin mengetahui apoptosis yang terjadi pada sel $\mathrm{t}$ rakea menggunakan parameter gambaran $\mathrm{i}$ munohistokimia caspase-3.

\section{BAHAN DAN METODE}

\section{Rancangan Penelitian}

Rancangan penelitian yang digunaan adalah eksperimental laboratorium.

\section{Tempat dan Waktu Penelitian}

Penelitian ini dilakukan di Laboratorium Radiologi Rumah Sakit Saiful Anwar Malang dan Laboratorium Patologi Anatomi FKUB.

\section{Sampel Penelitian}


Sampel yang digunakan adalah tikus putih Rattus norvegicus galur Wistar dengan usia 2-3 bulan dan berat badan $200 \mathrm{~g}$.

\section{Besar Sampel}

Jumlah sampel yang digunakan ada 27 ekor tikus dengan masing-masing kelompok perlakuan terdiri dari 9 hewan coba.

\section{Variabel Penelitian \\ Variabel Bebas}

Variabel bebas yang digunakan adalah radiasi sinar gamma dosis tunggal sebesar 10 Gy dan radiasi sinar gamma dosis fraksinasi sebesar 2 Gy selama 5 hari.

\section{Variabel Kendali}

Variabel kontrol berupa hewan coba, alat pemeliharaan dan alat fiksasi saat pemberian radiasi.

\section{Variabel Tergantung}

Variabel tergantung berupa respon caspase-3 sel trakea tikus setelah diberi perlakuan.

Penelitian ini adalah penelitian eksperimental yang dilakukan dengan cara membandingkan hasil yang sudah didapat setelah perlakuan (post test) dengan kontrol. Dalam penelitian terdapat tiga kelompok perlakuan terhadap hewan coba, yaitu kelompok I (kontrol) yang tidak diberikan pemberian sinar gamma, kelompok II yang diberi dosis tunggal radiasi sinar gamma sebesar 10 Gy (dosis total $10 \mathrm{~Gy}$ ), dan kelompok III yang diberi dosis fraksinasi radiasi sinar gamma sebesar 2 Gy setiap hari selama 5 hari (dosis total $10 \mathrm{~Gy}$ ). Radiasi sinar gamma yang diberikan berasal dari emitor sinar gamma berbasis radioisotop cobalt-60.

Untuk mengamati efek akut yang terjadi pada sel kelenjar trakea setelah diberikan radiasi sinar gamma, semua tikus, baik kelompok yang diberi perlakuan ataupun kelompok kontrol dibedah dan diambil trakeanya kurang lebih 18 sampai 24 jam pasca radiasi. Trakea diambil dan diawetkan dalam formalin $10 \%$. Selanjutnya dibuat sediaan histologi dan dicat dengan metode imunohistokimia, menggunakan antibodi caspase-3. Kemudian diamati sel kelenjar submukosa yang mengekspresikan imunohistokimia caspase-3 di bawah mikroskop dengan perbesaran 40 kali. Sel yang mengekspresikan caspase-3 akan menunjukkan inti berwarna ungu dan sitoplasma berwarna coklat. Hasil pengamatan dihitung menggunakan program SPSS 18 for windows dengan menerapkan uji one way ANOVA dan uji Tukey dalam post hoc test dengan tingkat kepercayaan 0,05 .

\section{HASIL}

Gambaran sel trakea yang diberi pewarnaan secara imunohistokimia menggunakan antibodi caspase-3 menunjukkan sel dengan inti berwarna ungu dan sitoplasma berwarna coklat karena kerja antibodi caspase-3 di dalam sitoplasma. Pada pengamatan, sel yang positif terjadi juga pada sel trakea kelompok kontrol atau tanpa radiasi. Fenomena tersebut mungkin terjadi karena kematian sel melalui proses apoptosis secara fisiologis dapat terjadi pada semua organ (Gambar 1).

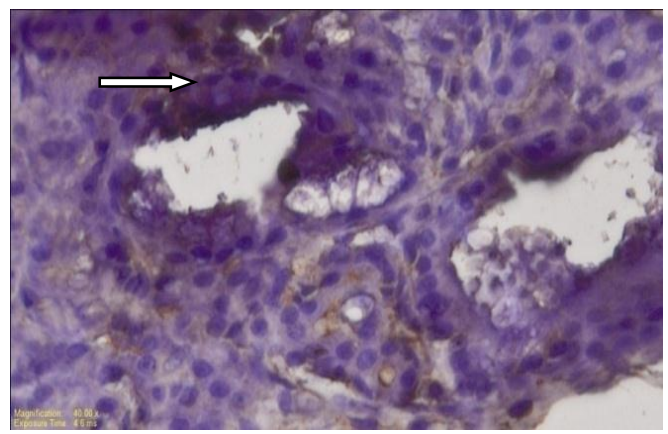

Gambar 1. Ekspresi caspase-3 (panah putih) pada sel trakea kelompok I (kontrol) yang tidak diberi radiasi sinar gamma. 


\begin{tabular}{cccc}
\hline No. & Kelompok & $\mathrm{N}$ & $\begin{array}{c}\text { Rata-rata sel } \\
\text { trakea/1000 sel } \\
(\mathrm{x} \pm \mathrm{SD})\end{array}$ \\
\hline 1. & Kontrol & 8 & $64,63 \pm 35,254$ \\
2. & Tunggal & 8 & $215,63 \pm 73,397$ \\
3. & Fraksinasi & 8 & $92,88 \pm 22,312$
\end{tabular}

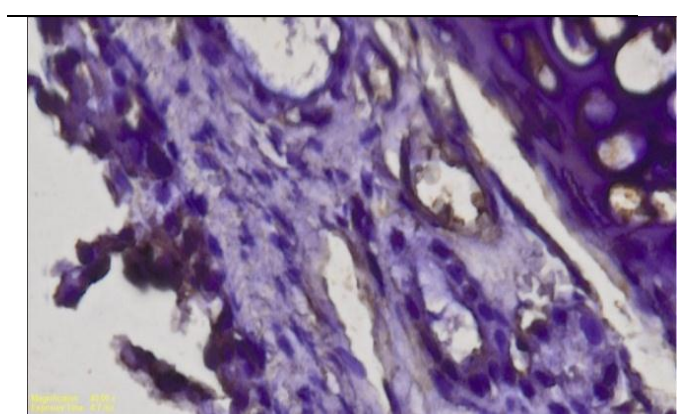

Gambar 2. Ekspresi caspase-3 (panah putih) pada sel trakea kelompok II yang diberi sinar gamma dosis tunggal (1x10 Gy)

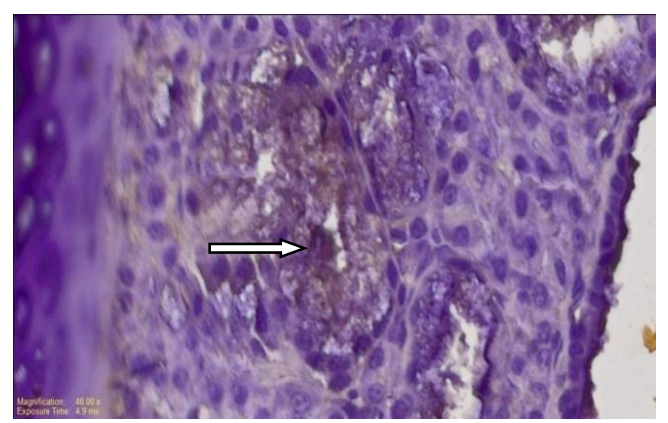

Gambar 3. Ekspresi caspase-3 (panah putih) pada sel trakea kelompok III yang diberi sinar gamma dosis fraksinasi (5x2 Gy).

\section{Analisis Data}

Sediaan jaringan trakea yang telah dicat dengan pewarnaan imunohistokimia menggunakan antibodi caspase-3 diamati dengan mikroskop dengan perbesaran 40 kali. Pengamatan ini dilakukan untuk menghitung sel trakea yang mengekspresikan caspase-3. Pada tiap sediaan, jumlah sel yang diamati adalah sebanyak 1000 sel dan akan dihitung berapa sel yang positif mengekspresikan caspase-3 untuk kemudian dihitung persentase. Akibat kurang optimalnya proses pewarnaan dan beberapa keterbatasan penelitian yang menyebabkan terlepasnya satu organ pada masing-masing slide. Maka jumlah preparat yang awalnya 9 pada masing-masing kelompok menjadi 8 preparat, sehingga jumlah total 24. Pada Tabel 1 dan Gambar 4 ditampilkan rata-rata sel trakea yang mengekspresikan caspase-3.

Tabel 1. Rata-rata jumlah sel trakea yang mengekspresikan caspase-3 (dalam persen)

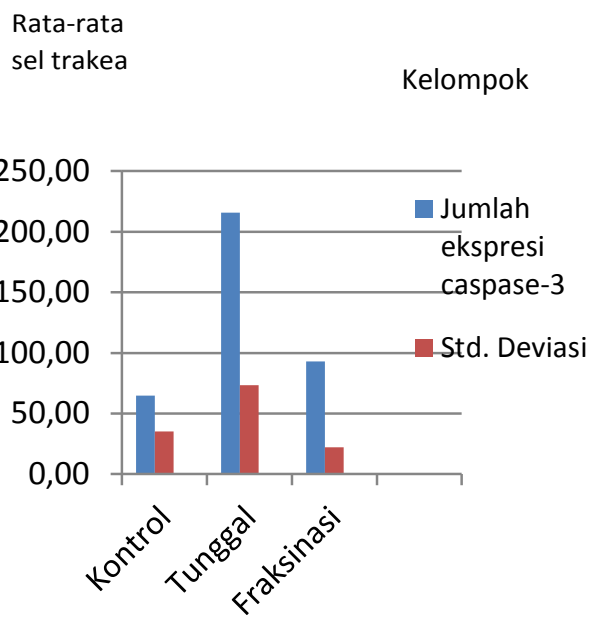

Gambar 4. Rata-rata sel trakea yang mengekspresikan caspase-3 pada tiap-tiap kelompok.

\section{PEMBAHASAN}

\section{Efek Radiasi Sinar Gamma terhadap Ekspresi Caspase-3 Sel Trakea}

Berdasarkan hasil di atas, diperoleh rata-rata sel trakea yang mengekspresikan caspase-3 pada setiap kelompok perlakuan. Peningkatan respon caspase-3 yang terjadi pada kelompok radiasi dosis tunggal maupun dosis fraksinasi terlihat lebih tinggi dibandingkan kelompok tanpa radiasi atau kontrol. Pada kelompok radiasi dosis tunggal menunjukkan peningkatan rata-rata jumlah ekspresi caspase-3 yang lebih besar dibandingkan jumlah ekspresi caspase-3 pada kelompok radiasi dosis fraksinasi. Hasil uji statistik one way ANOVA,menunjukkan peningkatan rata-rata sel trakea yang mengekspresikan caspase- 3 berbeda secara 
signifikan, dengan nilai signifikasi $0,000(p<$ 0,05 ). Hal tersebut sesuai dengan teori pada pembahasan bahwa radiasi berupa sinar gamma dapat meningkatkan apoptosis sel yang prosesnya berkaitan erat dengan respon caspase-3. Telah dijelaskan bahwa radiasi sinar gamma dapat merusak DNA sel yang kemudian menyebabkan terhentinya siklus sel.

Setelah diketahui bahwa perbedaan rata-rata jumlah sel yang mengekspresikan caspase-3 berbeda secara signifikan pada uji one-way ANOVA, maka selanjutnya dilakukan uji Tukey dalam post hoc test untuk mengetahui perbedaan persentase rata-rata antar kelompok perlakuan terlihat secara nyata atau tidak. Dari hasil perhitungan, menunjukkan bahwa pada kelompok I (kontrol) dengan kelompok II (radiasi dosis tunggal sebesar $10 \mathrm{~Gy}$ ) memiliki perbedaan rata-rata yang nyata dengan nilai signifikasi $0,000(p<0,05)$. Pada kelompok I (control) dibandingkan dengan kelompok III (radiasi dosis fraksinasi total sebesar 10 Gy yang diberikan $2 \mathrm{~Gy}$ selama 5 hari) tidak memiliki beda rata-rata yang jelas dengan nilai signifikasi $0,490(p<$ 0,05 ). Sementara pada kelompok II (radiasi dosis tunggal sebesar $10 \mathrm{~Gy}$ ) yang dibandingkan dengan kelompok III (radiasi dosis fraksinasi total sebesar 10 Gy yang diberikan 2 Gy selama 5 hari) memiliki beda yang nyata dengan nilai signifikasi $0,000(p<$ 0,05).

Pada kelompok I (kontrol) yang dibandingkan dengan kelompok II (radiasi dosis tunggal sebesar $10 \mathrm{~Gy}$ ) menunjukkan perbedaan respon caspase-3 yang nyata. Hal ini menunjukkan bahwa pemberian radiasi sinar gamma menyebabkan peningkatan jumlah apoptosis sel yang sangan besar, tingginya respon apoptosis ini sesuai dengan hipotesis yang diambil. Semakin besar dosis radiasi yang diberikan, semakin besar kemungkinan sel akan mengalami kematian. Jika melewati ambang batas kemampuan regenerasi, sel akan segera mengalami apoptosis dan tidak mampu melakukan perbaikan diri.
Hasil penelitian pada kelompok I (kontrol) dan kelompok III (radiasi dosis fraksinasi total sebesar 10 Gy yang diberikan 2 Gy selama 5 hari) menunjukkan bahwa jumlah respon caspase-3 sel trakea pada pemberian radiasi sinar gamma dosis fraksinasi tidak berbeda secara signifikan jika dibandingkan dengan sel trakea tanpa diberi radiasi. Hal tersebut terjadi karena rentang waktu yang ada pada setiap serial radiasi memberikan kesempatan pada sel untuk melakukan regenerasi dan perbaikan diri sehingga tidak terlalu banyak tampak sel yang mengalami apoptosis. Selain itu dapat terlihat bahwa kemampuan perbaikan diri pada sel trakea hewan coba cukup baik, hal ini dipengaruhi banyak faktor seperti imunitas.

Pada kelompok II (radiasi dosis tunggal sebesar $10 \mathrm{~Gy}$ ) yang dibandingkan dengan kelompok III (radiasi dosis fraksinasi total sebesar 10 Gy yang diberikan 2 Gy selama 5 hari) menunjukkan respon caspase-3 yang berbeda secara nyata berdasarkan gambaran sel trakea yang mengaktifkan jalur apoptosis lebih banyak terlihat pada kelompok radiasi dosis tunggal. Fenomena ini terjadi karena pada radiasi dosis tunggal diberikan dosis yang cukup tinggi untuk membuat sel mengalami apoptosis. Pada kelompok radiasi dosis fraksinasi tidak terlalu tampak respon caspase-3 karena dengan pemberian dosis $2 \mathrm{~Gy}$, sel masih mampu untuk bertahan dan memperbaiki diri, sedangkan jeda waktu antar dua radiasi adalah satu hari, hal ini memungkinkan sel melakukan self healing sehingga meskipun jumlah radiasi total sama dengan $10 \mathrm{~Gy}$. Namun, adanya jeda waktu setiap pemberian $2 \mathrm{~Gy}$ radiasi menyebabkan sel mampu bertahan dan tidak menyebabkan sel mati.

\section{Implikasi terhadap Bidang Kedokteran}

Dosis radiasi pada bagian kepala dan leher berbandig lurus dengan kerusakan kelenjar pada lapisan submukosa trakea. Pemberian dosis radiasi pada bagian kepala dan leher menyebabkan terjadinya penurunan signifikan pada produksi sekret 
oleh kelenjar. Pengaruh radiasi lebih terlihat pada kelenjar yang menghasilkan sekret cair seperti kelenjar saliva, begitu pula terjadi pada kelenjar serous pada lapisan submukosa trakea. Perubahan yang terjadi adalah keradangan secara akut yang diikuti penurunan jumlah kelenjar karena kerusakan. ${ }^{7}$

Pada aplikasi medis, terapi radiasi pada sel kanker dengan cara mengarahkan sinar radiasi ke sel target, namun faktanya ada sel normal di sekelilingnya yang terkena radiasi. Hal inilah yang akan menyebabkan sel normal mengalami apoptosis dan pembentukan radikal bebas yang bertindak sebagai prekursor kanker baik di organ target maupun di tempat lain. Sebagai contoh adalah terapi radiasi bagi kanker nasofaring. Radiasi diarahkan pada bagian leher saja namun organ di sekelilingnya seperti trakea dan esofagus juga akan terkena sinar, hal ini yang menyebabkan sel normal pada trakea juga mengalami apoptosis. Semakin tinggi dosis radiasi, semakin tinggi jumlah sel kanker yang mati, namun semakin besar juga dampak kerusakan sel normal yang berada di sekitar target organ. Pernyataan tersebut sesuai dengan hipotesis dan hasil penelitian yang menunjukkan bahwa radiasi dosis tunggal menyebabkan apoptosis sel yang lebih besar dibandingkan dengan radiasi dosis fraksinasi.

Pada bidang klinis, radiasi terapi hanya diberikan sekitar 1,8 Gy sampai dengan $2 \mathrm{~Gy}$ dalam sekali penyinaran dan dosis total yang diberikan tergantung stadium dan tingkat keparahan kanker. Terapi radiasi diberikan dalam beberapa kali penyinaran dengan dosis maksimal 2 Gy dalam sekali penyinaran bertujuan untuk memberikan kesempatan bagi tubuh untuk regenerasi sel. Target terapi berjalan lebih lama namun efek samping kerusakan sel normal di sekeliling target organ lebih ringan meskipun tetap ada kejadian apoptosis sel normal dan memungkinkan menyebabkan masalah baru pasca radiasi. Hal ini sesuai dengan hasil penelitian yang menunjukkan bahwa sel trakea yang diberi radiasi dosis fraksinasi mengalami apoptosis sel yang lebih banyak dibandingkan dengan sel normal tanpa radiasi meskipun hasilnya tidak terlalu signifikan atau berbeda jauh.

\section{Keterbatasan Penelitian}

Dalam penelitian ini terdapat beberapa keterbatasan antara lain:

- Penyinaran terhadap hewan coba yang mengenai dorsal sehingga menyebabkan radiasi tidak optimal mengenai bagian leher tikus. Hal ini disebabkan terbatasnya alat fiksasi terhadap hewan coba.

- Organ trakea direndam formalin terlalu lama. Kondisi ini menyebabkan ekspresi caspase 3 tidak optimal.

- Lepasnya beberapa organ dari object glass yang mungkin dikarenakan kualitas object glass yang kurang baik, proses pembuatan preparat yang tidak optimal atau proses staining yang kurang bagus.

- Proses radiasi dosis fraksinasi yang kurang lama pada rest time karena terbatasnya waktu penelitian dan tidak diberikan makanan yang mengandung antioksidan sehingga sama seperti proses radiasi yang dilakukan pada manusia.

\section{KESIMPULAN}

Berdasarkan hasil penelitian, disimpulkan bahwa pemberian radiasi sinar gamma dosis tunggal $10 \mathrm{~Gy}$ (1x10 Gy) dapat menyebabkan ekspresi caspase-3 yang lebih tinggi daripada pemberian radiasi sinar gamma dosis fraksinasi 10 Gy (5x2 Gy) pada sel trakea.

\section{SARAN}

- Perlu diperhatikan waktu yang dibutuhkan dalam setiap prosedur mulai dari euthanasia, pengambilan organ, pembuatan slide dan pengecatan agar tidak mengurangi ekspresi apoptosis sel.

- Pengamatan slide dan penghitungan sel apoptosis sebaiknya dilakukan oleh lebih dari satu orang untuk menghindari subjektifitas saat penghitungan. 
- Perlu dilakukan penelitian lebih lanjut untuk mengamati efek radiasi pada sel normal di sekeliling sel kanker yang diberi radioterapi agar ditemukan cara meminimalkan efek samping radiasi.

- Mengingat penelitian tentang trakea sangat minimal maka diperlukan penelitian lebih lanjut dengan dosis radiasi beragam ataupun variabel bebas yang berbeda.

\section{DAFTAR PUSTAKA}

1. Affandi A. Prinsip Terapi Radiasi dalam THT. Riau. 2009. Hal. 2-14.

2. Diaz, et al. lonizing radiation-Induced Oxidative stress Alters miRNA Expression. 2011..(Online). (http://www...plosone.org/article/info:doi/1 0.1371 /journal.pone.0006377. Diakses 22 Desember 2012.

3. Kreshnamurti I, Ginting R, dan Dina F. Refrat Radioterapi: Radioterapi pada Kanker Serviks. 2005. (Online). (http://digilib.unsri.ac.id/download/DasarDasar\%20Radioterapi.pdf. Diakses tanggal 14 Desember 2011.

4. Guyton AC dan Hall JE. Buku Ajar Fisiologi Kedokteran. Irawati $D$ et al.
(Penerjemah). Edisi ke-11. Jakarta: EGC Medical Publisher. 2008. Hal. 41, 609610.

5. Albertsson M. Dose-Response Studies of Single Dose lonizing Radiation on the Ciliated Epithelium of the Trachea of the Rabbit. A Physiologic and Ultrastructural Investigation. Acta Radiol Oncol. 1985; 24(5):433-443.

6. Arma AJ. Zat Radioaktif dan Penggunaan Radioisotop bagi Kesehatan. 2004. (Online),

(http://repository.usu.ac.id/bitstream/1234 56789/3763/1/biostatistikabdul\%20jalil.pdf. Diakses 24 Desember 2012.

7. Suyuti. Keluhan Mulut Kering Ditinjau dari Faktor Penyebab, Manifestasi dan Penanggulangannya. Sumatra Utara. 2002. Hal. 6-35. 